\title{
Determining Factors of the Broiler Farmer's Profitability under the Partnership Program in Tomohon, North Sulawesi-Indonesia
}

\author{
Lidya S. Kalangi*',Stanly O. B. Lombogia, and Jeane Pandey \\ Faculty of Animal Husbandry, Sam Ratulangi University, North Sulawesi, Indonesia
}

\begin{abstract}
The partnership program conducted by broiler farmers using a limited capital is continuously developing due to the beneficial profitability. However, in a certain period, broiler farmers do not gain an expected profit (sometimes suffering loss) as various input and output factors, mortality and land ownership occur. The research, then, aims to comprehend the profitability of the broiler business and analyze determining factors of broiler farmer's profitability, utilizing the openhouse cage system under the partnership program. Technically, the sampling method of the respondent was purposively determined, and the data collecting technique was through interview, observation, and recording on 30 farmers existing in Tomohon, North Sulawesi. In detail, all collected data were economically and descriptively analyzed, and the multiple-regression analysis employed Eviews 11 program. As a result, the finding of this research shows that the value of $\mathrm{R} / \mathrm{C}$ was 1.12 , and variables having positive and significant meaning to profit were demonstrated by a total of feeds, and the dummy of the proprietorship; while, the variable of mortality had negative and significant meaning on the profit of broiler farmer. Further, the profitability gained by broiler farmers in the Province of North Sulawesi can be improved by increasing the total of feeds, decreasing mortality, and having broiler businesses in their private land/cages independently.
\end{abstract}

\section{Introduction}

A broiler is one of the livestock commodities, potentially developed to produce meat as the main product and protein source. Its rapid production and stable market demand, which also increases during certain National holidays, make the broiler business having a promising and large profit. Regulation of Minister of Agriculture No. 13 of 2017 on husbandry partnership program that is a partnership of inter-husbandry business based on the principle of mutual strengthening, demanding, benefiting, respect, responsibility, and dependency. Typically, the partnership program of broiler business follows a main-plasma design, describing the partnership of the husbandry company or other sectors, being the main company, and farmers as its plasma.

\footnotetext{
* Corresponding author: lidya.kalangi@unsrat.ac.id
} 
In the partnership program of broiler industry, breeder, being the plasma, obtains guarantee of DOC supply, feeds, disinfectant vaccine (OVD) and marketing, and marketing based on contract's price under a written agreement with the main company. Usually, the breeder provides cage, equipment, and labor to raise and keep the broiler from DOC to harvest time. The main company, then, is responsible to take and manage all harvests of living birds (LB) from farmers based on the contract's price [7].

The breeder's intention to raise broiler under partnership program is increasing because of its profitability. However, some broiler farmers in the City of Tomohon start their business with limited capital. Those having limited capital only rely on leased fields, cages, and equipment. Presumably, the breeder's profit in the broiler industry using their field, cage, and equipment is assumedly different from farmers using leased fields, cage, and equipment. In some previous researches, it explains that the profitability of broiler farmers is influenced by input factor, production cost, and socio-economy characteristic of the farmers $[5-8,10,12,13]$. Nonetheless, none of that research inserts dummies the variable of proprietorship in their study.

This research aims to comprehend the profitability of the broiler business and analyze determining factors of the profitability from broiler farmers using the open-house model of the cage system under the partnership program.

\section{Research Method}

The research was conducted in the City of Tomohon. The consideration was that the population of broilers in the City of Tomohon was the third largest of the Province of North Sulawesi, followed by North Minahasa, and the City of Kotamobagu. Moreover, the city is in the highland, which has $>700 \mathrm{~m}$ above sea level. Methodologically, the data collecting technique was interview and site observation. There were two types of collected data, such as primary and secondary. The primary data was obtained from direct observation and the interview result using a questionnaire related to both technical and financial aspects. It comprised of data of production input during the second period of rising in 2021.

44 broiler farmers were recorded based on information from the Service of Agriculture and Fishery of the City of Tomohon. In this research, the sample was 30 respondents, comprising of 13 respondents with the leased land/cages (determined by the total of samples), and 17 respondents with private land/cages (determined by a simple random sampling method). In addition, the respondents of the study were labor and owner of the broiler industry. All collected data were descriptively and quantitatively edited, tabulated, and analyzed. The considered variables were production cost, income, and profit.

The impacts of the total of DOC, a total of feeds, medicine and chemical vaccine cost, labor cost, mortality, and the dummy of ownership to profitability were analyzed using multiple linear regressions by Eviews 11 program. Hence, the regression equation was obtained, as follows:

Where:

$$
Y=a+b_{1} X_{1}+b_{2} X_{2}+b_{3} X_{3}+b_{4} X_{4}+b_{5} X_{5}+D+e
$$

$\mathrm{Y} \quad$ : Profitability of broiler business (IDR/period)

$\mathrm{X}_{1} \quad$ : Total of DOC (broiler/period)

$\mathrm{X}_{2} \quad$ : Total of Feeds $(\mathrm{kg} / \mathrm{period})$

$\mathrm{X}_{3} \quad$ : OVK Cost (IDR/period)

$\mathrm{X}_{4} \quad:$ Labor Cost (IDR/period)

$\mathrm{X}_{5} \quad$ : Mortality (broiler/period)

D : Dummy of filed, cage, and equipment proprietorship $(1=$ private; $0=$ lease $)$ 


$\begin{array}{ll}\mathrm{a} & : \text { Constanta } \\ \mathrm{b}_{1}, \mathrm{~b}_{2}, \mathrm{~b}_{3}, \mathrm{~b}_{4}, \mathrm{~b}_{5} & : \text { Regression coefficient } \\ \mathrm{e} & : \text { Error }\end{array}$

\section{Result and Discussion}

The respondents of farmers in the City of Tomohon established a partnership with 5 companies, such as PT. Ciomas, PT. BSB (Bintang Sejahtera Bersama), PT. Kartika Eka Dharma, PT. DMC (Dinamika Megatama Citra), and PT. Celebes. All companies procured production infrastructures of DOC (Day Old Chicken), feed, medicine, and vitamin. Production infrastructures provided by the main companies were directly delivered to the site of broiler husbandry/cage. Those were given by the main company under a loan or credit system, where the full payment or credit return was deduced from income obtained by plasma, farmers, in a one-time production period. Additionally, the guarantee of farmers as plasma dependent on the total of DOC following the cage's capacity. The guaranteed value per broiler was different for each company.

Technically, the main company assigned a counseling officer to supervise and direct about raising technique, which each company had a different counseling period. The marketing of the production result was, then, determined by the main company based on the breeder's information related to harvest time. All ready-harvested broilers were purchased by the seller directly coming to the husbandry site bringing receipt of purchasing from the main company. A prevailing price was in line with the broiler's weight as drafted in agreement.

\subsection{Characteristics of Respondents}

The socio-economic characteristics of respondents were based on age, education level, and experience, as seen in the following Table 1. Those farmers as respondents ranged at 22-70 years of old, where the biggest percentage was at 3-40 years old and above (40\%), and the following was more than 60 years old (27\%). Further, the result performed by Isa (2019) showed that the involvement of farmers aged 51 years old and above is economically more stable since they have many experiences in the broiler industry [3, 12].

Table 1. Socio-Economic Characteristics of Respondent in the City of Tomohon

\begin{tabular}{|c|c|c|}
\hline Details & Total & $\%$ \\
\hline Age (years old) & & \\
\hline $21-30$ & 4 & 13 \\
\hline $31-40$ & 12 & 40 \\
\hline $41-50$ & 4 & 13 \\
\hline $51-60$ & 2 & 7 \\
\hline$>60$ & 8 & 27 \\
\hline Education Level & & \\
\hline Elementary & 2 & 7 \\
\hline Junior High School & 6 & 20 \\
\hline Senior High School & 15 & 50 \\
\hline Undergraduate & 7 & 23 \\
\hline Experience (years) & & \\
\hline $1-5$ & 16 & 53 \\
\hline $6-10$ & 5 & 17 \\
\hline$>10$ & 9 & 30 \\
\hline
\end{tabular}


Based on the above table, farmers being respondents in this research, had a varied education level, starting from Elementary up to Higher Education, university. The largest educational level of respondents were Senior High School (15 farmers or 50\%), Undergraduate ( 7 farmers or 23\%), Junior High School (6 farmers or 20\%), and Elementary ( 2 farmers or $7 \%$ ).

In addition, the experience in managing husbandry conducted by respondents in the City of Tomohon had less than 5 years, dominating with 16 respondents $(53 \%)$. There was $30 \%$ of respondents having more than 10 years of experience. It, then, demonstrates that most farmers had no sufficient experience, where a better education level had a vital role in the productivity of the broiler business. As the result, a well-experienced and educated breeder could be faster in adopting new technology innovations [11].

\subsection{Financing, Income, and Profitability}

Below, Table 2 displays the component of cost, income, and profitability from broiler business in the City of Tomohon. Averagely, the biggest component of the cost was used for feeding or $68.04 \%$. It followed by DOC cost $(25.64 \%)$, labor cost $(1.66 \%)$, LPG cost $(0.87 \%)$, medicine, vitamin, and vaccine cost $(0.78 \%)$, cost of husk $(0.58 \%)$, and electricity cost $(0.23 \%)$. The ownership rate of farmers under the partnership program was 5,767 broilers/period, and the mortality was $2.6 \%$. It argued that this mortality can impact the value of the Feed Conversion Ratio (FCR) and the farmers' profitability of the broiler industry [8].

Table 2. Rate of Breeder's Cost and Income in the City of Tomohon, Province of North Sulawesi

\begin{tabular}{|c|r|}
\hline Details & \multicolumn{1}{|c|}{ Total (IDR) } \\
\hline DOC & $49,891,666.67$ \\
\hline Feed & $132,400,562.5$ \\
\hline Medicine and vaccine & $1,526,061.111$ \\
\hline Labor & $3,235,833.333$ \\
\hline Husk & $1,123,450$ \\
\hline Electricity & $448,666.6667$ \\
\hline LPG & $1,691,666.667$ \\
\hline Total of costs & $194,585,011.8$ \\
\hline Profit & $24,113,027.49$ \\
\hline Income & $218,718,196.7$ \\
\hline R/C & 1.12 \\
\hline
\end{tabular}

From the above table, the total of costs was the rate of aggregate costs, including depreciation cost of cage and equipment and leasing cost of field, cage, and equipment [4]. All equipment used had to be cleaned as entering the first raising period. They had economically different duration where it caused different depreciation costs.

Furthermore, the value of RC ratio was 1.12 , describing that every IDR 1,000 invested for broiler production in the City of Tomohon produced IDR 1,120. The result of this research was different from previous researches, where its value was varied, such as 1.07; $1.08 ; 1.32[2,7]$

\subsection{Determining Factors of the Profitability in Broiler Business}

According to the result of regression analysis in the following Table 3, F value (27.43) exhibits that variable of the total of DOC $\left(\mathrm{X}_{1}\right)$, the total of feeds $\left(\mathrm{X}_{2}\right)$, cost of medicine, vitamin and vaccine $\left(\mathrm{X}_{3}\right)$, labor cost $\left(\mathrm{X}_{4}\right)$, a total of dead broilers $\left(\mathrm{X}_{5}\right)$, and the dummy of field, cage, and equipment proprietorship had a significant impact to the profitability of 
broiler industry $(\mathrm{P}<0.01)$. In addition, based on those variables, the coefficient value of determination, $\mathrm{R}^{2}$ (adjusted), was 0.85 , where the fluctuation of the profitability was $85 \%$. Meanwhile, the rest was $15 \%$ described by other variables outside of the model.

Table 3. Regression Analysis Result on Income of Broiler Business

\begin{tabular}{|c|l|l|l|c|}
\hline Variable & Coefficient & Std. Error & t-Statistic & Prob. \\
\hline $\mathrm{C}$ & -6178415 & 3519165 & -1.755648 & 0.0925 \\
\hline $\mathrm{X}_{1}$ & 1198.972 & 2137.979 & 0.560797 & 0.5804 \\
\hline $\mathrm{X}_{2}$ & 1539.648 & 706.5841 & 2.179001 & 0.0398 \\
\hline $\mathrm{X}_{3}$ & -1.555935 & 1.283817 & -1.211960 & 0.2378 \\
\hline $\mathrm{X}_{4}$ & 0.862379 & 0.697065 & 1.237158 & 0.2285 \\
\hline $\mathrm{X}_{5}$ & -29302.04 & 15260.92 & -1.920070 & 0.0673 \\
\hline $\mathrm{D}$ & 5424521 & 2837020 & 1.912049 & 0.0684 \\
\hline R-squared & 0.877367 & & \\
\hline Adjusted R-squared & 0.845376 & \multicolumn{5}{|l}{} \\
\hline F-statistic & 27.42529 & \\
\hline Prob(F-statistic) & 0.000000 & \\
\hline
\end{tabular}

According to the above table, the variable of the total of DOC $\left(\mathrm{X}_{1}\right)$ had a positive impact on profitability. This impact was due to the total of DOC was heavily dependent on the availability of the cage capacity. The more increasing the total of DOC in the first raising period, the more improving the population of harvest by the end raising period. Consequently, the increasing total of the harvest will result in the breeder's income [7, 10].

Also, the total of feeds $\left(\mathrm{X}_{2}\right)$ had a significantly positive impact $(\mathrm{P}<0.05)$ on profitability since there was an increasing total of feeds followed by the addition of broiler's weight. In short, the total of feeds improved the profitability if there was a small rate of mortality.

However, the variable of medicine and vitamin cost $\left(\mathrm{X}_{3}\right)$ had an insignificantly negative impact on profitability. It means that medicine and vitamin cost had no significant impact on profitability obtained by farmers in the City of Tomohon. Then, this situation indicates that there was a gap in health management among farmers, where it was dependent on the task of the counseling officer from each main company, broiler's condition, and surroundings. The utilization of medicine, vaccine, and vitamin are necessarily required to solve outbreaks, improve immunity, and support broiler's growth.

While the variable of labor cost $\left(\mathrm{X}_{4}\right)$ had a positive impact on profitability, this finding was similar to the study performed by Lestari [7], but contradicted the previous findings [10]. The labor cost was related to the raising management of broiler. Some respondents were capital owners, waging to labor based on the total of living broilers before the harvest time. Thus, labor would maximally work hard to reduce mortality. It means that an incentive given to farmers would motivate their labor in intensifying their work in raising broilers, such as continuous feeding, maintaining cage hygiene, controlling broiler's health, and being discipline by complying with instructions and manual provided by the main company.

Based on the result of regression analysis, it provides that the variable of mortality $\left(\mathrm{X}_{5}\right)$ was -29302 , where if one broiler was dead, the profitability would decrease as of IDR 29,302,-. The more increasing mortality of broilers would significantly reduce the profitability $(\mathrm{P}<0.10)$. Some influencing factors of a higher rate of mortality were unhealthy DOC, climate, outbreak, and poor raising management. To prevent such conditions, the main company provided a bonus, if plasma, farmers, could minimize the mortality in line with the standard as stipulated in agreement [2, 9]. Subsequently, the 
previous research argued that the mortality experienced by contractual broiler industry was $4.23 \%$, lower than non-contractual broiler business, such as $5.88 \%$ [1]

The dummy of the ownership of land, cages, and tools had significant and positive value $\quad(\mathrm{P}<0.10)$, demonstrating that broiler farmers with private land or cages would gain larger profit than broiler farmers leasing land, or cages. It was because farmers had expensed additional costs for leasing the field, cage, and equipment. Therefore, the status of farmers having their land, cage, and equipment had a positive impact in increasing profitability. Specifically, 13 respondents had no private property of field, cage, and equipment in raising broilers. In detail, some respondents only leased fields, and some rented fields, cages, and equipment. The total costs were dependent on both the feasibility of the cage facility/installation and the availability of its equipment. Equipment, utilized in the broiler industry, comprised of feed container, drinking box, fan, cage heater, sprayer, curtain, water reservoir, scale, thermometer, and chick guard.

\section{Conclusion}

Based on the value of $\mathrm{R} / \mathrm{C}$ as of 1.12 , the profitability achieved by broiler farmers in the City of Tomohon is feasibly improved as the main living. Determining factors having a significantly positive impact on the profitability comprise the total of feeds and dummy of proprietorship, cage, and equipment; while, the mortality has a significantly negative impact on the profitability of broiler breeder.

The profitability of broiler farmers could be improved by better raising management. It could be done by increasing the total of feeds, evenly distributed to broilers, decreasing mortality by considering cages' sanitation and hygiene, and having broiler business in their private land and cages. However, the research was only limited to broiler farmers under the partnership program and using the open-house system of cages. Further, the following researches can necessarily compare the profitability gained by private farmers and farmers utilizing the close-house system of cages. The profitability obtained by broiler farmers living in the highland is also compared with those in the lowland.

Acknowledment. The researcher would like cordially to thank the Rector of Sam Ratulangi University for valuable assistance in supporting and endorsing this research via the 2021 UNSRAT Internal Funds based on the scheme of UNSRAT Flagship Research (RDUU).

\section{References}

1. A.K. Singh, M.P. Sagar, J. Pratap and A.K. Chaturvedani. Int.J.Curr.Microbiol.App.Sci 7, 2624 (2018)

2. A.T. Murti, B. Hartono, Z. Fanani. J-PAL 6, 2 (2015)

3. A. H. Md. Isa, M.M. Ismail, N. S. Samsuddin, and I. Abdurofi. International Journal of Business and Society, 20, 521 (2019)

4. A.S. Shaikh and Y.C. Zala. Agricultural Economics Research Review, 24, 317 (2011)

5. M. Khan and M. Afzal. Sarhad Journal of Agriculture, 34, 389 (2018)

6. N. Hasanah and Z. Fanani. Journal of Development Research, 2 , 28 (2018)

7. R.I. Lestari, K. Budiharjo dan M. Handayani. Jurnal Pengembangan Penyuluhan Pertanian, 13, 47 (2016) 
8. S.M.R. Samarakoon, and K. Samarasinghe. Tropical Agricultural Research, 23, 338 (2012)

9. L.S. Kalangi, S.O.B. Lombogia, and M.N. Regar. IJABIM, 6, 14 (2021)

10. N. Mukunthana and P. Sivarajahb. 4 th Annual International Research Conference (2015)

11. I. Abdurofi, M.M. Ismail, H.A.W. Kamal, and B.H. Gabdo. International Food Research Journal, 24, 761 (2017)

12.P.C. Ike and C.O.A. Ugwumba. International Journal of Poultry Science, 10, 106 (2011)

13. E. Seth, G.K. Nurah and A. Ohene-Yankyera. Journal of Business \& Economics, 5, 228 (2013) 